\title{
The Bankruptcy Decision and Debt Contract Renegotiations *
}

\author{
ELAZAR BERKOVITCH ${ }^{1}$ and RONEN ISRAEL ${ }^{2}$ \\ ${ }^{1}$ Tel Aviv University \\ ${ }^{2}$ University of Michigan Business School, 701 Tappan Street, Ann Arbor, MI 48109-1234, \\ U.S.A.(Corresponding author)
}

\begin{abstract}
We consider the bankruptcy law and workout practices in the United States and model bankruptcy as a strategic decision. We analyze a firm's choice between liquidation under Chapter 7 , renegotiation of the debt contract in a workout, and reorganization under Chapter 11 of the bankruptcy code. Our premise is that a financially distressed firm chooses its action in order to minimize the loss in value caused by the well-known over- and under-investment problems. We show that the firm initiates a workout when it faces under-investment, and commences Chapter 11 when it faces over-investment. Some of the results are: (i) in default, total firm value and equity value increase upon the announcement of a workout and decrease upon the announcement of Chapter 11; (ii) firms with shorter maturity of debt are more likely to reorganize in a workout; (iii) among the firms that renegotiate their debt contract, the proportion of firms entering Chapter 11 is higher for firms in mature industries than for firms in growth industries.
\end{abstract}

Financial distress may cause traumatic events like default, bankruptcy, liquidation or reorganization, whose resolution has a great impact on a firm's financial and economic policies. Several actions are available to firms to alleviate the costs of these events, among which are commencing Chapter 11 or Chapter 7 of the bankruptcy code, out-of-court workout negotiations to change the debt contract, and open-market liquidation. In order to better understand the behavior of financially distressed firms, their choices over this entire set of actions must be considered. In this paper, we explore the determinants of the bankruptcy decision in the presence of the other options to resolve the conflict between debtors and creditors.

Several puzzling issues arise when bankruptcy is viewed as a strategic decision. First, why do firms commence Chapter 11 instead of directly negotiating with

$\star$ We thank Ed Altman, Lucian Bebchuk, Simon Benninga (the Editor), Jim Bohn, David Brown, Harry DeAngelo, Mike Fishman, Jacob Glazer, Jon Glover, Kathleen Hagerty, Rob Heinkel, Kose John, Avner Kalay, Naveen Khanna, Marc Lipson, M. P. Narayanan, Jonathan Paul Carmel, Artur Raviv, Raj Singh, Rene Stulz, Jaime Zender, an anonymous referee, Seminar participants at The University of Michigan, Tel-Aviv University, The Hebrew University, NYU, Columbia University, The Western Finance Association meetings, The European Finance Association meetings, and The Finance Winter Conference in Utah for their helpful comments and suggestions. 
debtholders, thereby saving the costs of court settlement? ${ }^{1}$ Second, why are many firms liquidated in Chapter 11 instead of being liquidated in Chapter $7 ?^{2}$ Third, why is the absolute priority rule (APR) often violated in bankruptcy?

To address these issues in the absence of liquidity constraints, other frictions, such as information asymmetry or conflict of interest between claimholders, must be incorporated into the model. We focus on the conflict of interest between an owner/manager and debtholders. In the presence of risky debt, this conflict results in the well-known over- and under-investment problems. Our premise is that the manager of a financially distressed firm chooses its actions in order to minimize the loss in value due to these investment distortions.

We consider a firm with a standard debt contract, promising periodic payments to creditors. The manager, who is also the owner of the firm's equity, privately observes the characteristics of the investment opportunities, while the creditors investigate the firm and obtain an imperfect signal about these characteristics. If the creditors discover that the firm should be liquidated, they may file a Chapter 7 petition for liquidation. If they do not file a Chapter 7 petition, the owner/manager decides whether to (i) liquidate the firm, (ii) pay the current debt obligations and continue operations, or (iii) renegotiate the debt contract. Renegotiations can be done in a workout, i.e., directly with debtholders outside the bankruptcy court, or under court supervision in Chapter 11.

When renegotiation of the debt contract is ruled out, the firm's investment decision may be distorted in two ways. First, the manager may under-invest by refusing to finance a positive net present value (NPV) project if debt value is increased by more than the project's NPV. Second, the owner manager may have the incentive to over-invest by undertaking a negative NPV project if it reduces debt value by more than the project's NPV.

When the investment opportunity and the financial structure of the firm lead to under-investment, a workout can eliminate the distortion. In this case, since investment increases debt value, debtholders are willing to compensate the manager for undertaking value-increasing projects. Thus, debtholders will accept an offer that reduces the face value of debt but increases its market value.

The manager will not initiate workout, however, when the investment opportunity and the financial structure lead to over-investment. Since over-investment decreases firm and debt values, and since in Chapter 7 the firm is liquidated under strict APR, debtholders commence Chapter 7 to prevent the manager from over-investing. Therefore, the manager will initiate negotiations only when he is

\footnotetext{
1 In the presence of liquidity constraint, a possible rationale for commencing the costlier Chapter 11 is to obtain a 'breathing spell'. Another frequently cited explanation for why firms resort to the costlier Chapter 11, is the free-rider problem that may exist when the debt is widely held (see Gertner and Scharfstein, 1991).

2 The 1978 US Bankruptcy Code designed Chapter 7 for liquidation and Chapter 11 for reorganization. However, Flynn (1989) estimates that only about 10-12\% of Chapter 11 cases result in an actual reorganization of the filing entity. Franks and Torous (1989) find that the majority of firms that filed for Chapter 11 protection did not emerge from it.
} 
protected from debtholders. This protection in Chapter 11 is accomplished through the 'automatic stay'. In this respect, Chapter 11 enables negotiations to take place. In other words, Chapter 7 gives the debtholders so much bargaining power that it pays the manager to commence the costlier Chapter 11, in order to get protection and increase his bargaining power.

In Chapter 11, the court can affect the division of the surplus between the manager and the creditors by determining the negotiating agenda and threatening to cram down a reorganization plan. This enables the court to give the manager incentives to come forward and negotiate the debt contract, thereby preventing the loss in firm value. Thus, firms facing over-investment commence Chapter 11 even though it involves higher direct bankruptcy costs than a workout. ${ }^{3}$

To derive the empirical implications of our theory, we assume that the bankruptcy court implements the optimal policy according to our analysis. Based on this assumption, we obtain predictions regarding how a firm's earnings and growth opportunities affect its bankruptcy decision as follows.

(1) In Chapter 11 and in workout, the owner/manager's payoff is higher than the payoff he is entitled to under APR. The reason is, that paying the owner/manager above what he is entitled is required to induce him to make more efficient investment decisions.

(2) Among the firms that renegotiate their debt contract, the proportion commencing Chapter 11 is higher for firms in mature industries than for firms in growth industries. Firms in mature industries tend to have lots of cash and poor investment opportunities, so they are more likely to face over-investment incentives, and, therefore, commence Chapter 11.

(3) In Chapter 11, a firm's total value and a firm's equity value increase upon announcement of emergence from Chapter 11, and decrease upon liquidation.

(4) In default, total firm value and equity value increase upon the announcement of a workout and decrease upon the announcement of Chapter 11. This is so because workout filing reveals that the firm has positive NPV investments that will be financed following the completion of the workout negotiations.

(5) Holding the level of debt fixed, firms with a shorter maturity of debt are more likely to reorganize in a workout, and firms with a longer maturity of debt are more likely to commence Chapter 11 . The reason for this result is that debt with shorter maturity increases the likelihood that the firm will need external financing and therefore, face underinvestment incentives.

Several financial economists have studied the bankruptcy decision. Bulow and Shoven (1978), and White (1980) consider a firm's choice between continuation and liquidation. Harris and Raviv (1990) consider a firm's choice between liquida-

\footnotetext{
${ }^{3}$ Our paper identifies a role for Chapter 11 and Chapter 7 in enhancing both firm and social values. It may be argued that other mechanisms, such as auctions, are more efficient. As Easterbrook (1990) claims, however, the fact that the current system endured for so long implies that it has some advantages over other mechanisms.
} 
tion and reorganization. Brown (1989) shows how the rules of Chapter 11 affect the outcome of the renegotiation process. However, since this outcome serves only as a threat in the private renegotiation game, his theory does not explain actual bankruptcy filings. Gertner and Scharfstein (1991) consider restructuring both in workout and Chapter 11. Giammarino (1989) shows that uninformed debtholders may force the firm into a costly court settlement in order to separate solvent from insolvent firms. Bergman and Callen (1991), Bebchuk and Chang (1990), and Green and Juster (1994) study the negotiation process in reorganization. By allowing the firm to strategically choose from this exhaustive set of actions, consisting of continuation, liquidation, workout, and Chapter 11, we are able to address additional issues, including the questions posed above.

The paper is organized as follows. In Section 1 we present the basic model. In Section 2 we characterize the optimal investment policy and the resulting overand under-investment problems when renegotiation of debt is ruled out. In Section 3 we introduce the US bankruptcy code into the model. In Section 4 we incorporate workout negotiations into the analysis. In Section 5 we compare bankruptcy laws and practices in the US. The empirical implications are presented in Section 6, and Section 7 concludes. All proofs are relegated to the Appendix.

\section{The Basic Model}

We consider a firm that operates for two periods, period 1 and period 2. The firm has debt outstanding that specifies two promised payments, $P_{1}$ and $P_{2}$, to be paid in periods 1 and 2, respectively. The firm has assets in place that yield a random cash flow $X$ in period 1 . We assume that the liquidation value of the assets is zero, so the liquidation value of the firm in period 1 is $X{ }^{4}$ While the liquidation value $X$ may consist of both cash and proceeds from selling assets, we will assume in the analysis that $X$ consists of cash only. In addition, we assume that all agents are risk neutral and that the interest rate is zero.

The firm is managed by its owner. In period 1, the owner/manager makes an investment decision and decides whether to service the debt. In general, these decisions depend upon the current cash flow, $X$, the terms of the debt contract, and the firm's investment opportunities. The investment opportunities in period 1 yields a payoff in period 2 from investing $I$, according to the following production technology,

$$
f(I, \alpha) v
$$

where $I$ is the investment level, $v \in \mathfrak{R}^{+}$is a random variable with a c.d.f. $G$, representing the uncertainty about the outcome of the production process, and

\footnotetext{
4 The qualitative results of the paper would not change if the liquidation value was larger or smaller than $X$. The liquidation value would be larger than $X$ if the assets in place had a positive value, and would be smaller than $X$ if liquidating the firm was costly.
} 
$\alpha \in \mathfrak{R}^{+}$is a parameter representing managerial quality. We make the following standard assumptions regarding the production technology.

\section{Assumptions}

1. $f(I, \alpha)$ increases with both $I$ and $\alpha$, concave in $I$, and the marginal product of $I$ increases with $\alpha$, i.e., $f_{I}(I, \alpha)>0, f_{\alpha}(I, \alpha)>0, f_{I I}(I, \alpha)<0, f_{I \alpha}(I$, $\alpha)>0$.

2. $f_{I}(0,0) E(v)<1, f_{I}(0, \alpha) E(v) \geqslant 1$ for some $\alpha$, where $E(v)$ is the expected value of $v$.

Assumption 1 is made to simplify the analysis. Assumption 2 guarantees that some firms are economically viable while others should be liquidated.

Prior to period 1 , only the probability distributions of the quality parameter $\alpha$ and the cash flow $X$ are known to all. In period 1, before decisions are made, $\alpha$ is revealed to the manager but not to the debtholders, and $X$ is revealed to all. The debtholders investigate the firm and discover the value of $\alpha$ with probability $r$. With probability $1-r$ they continue to hold their prior beliefs regarding $\alpha$. The debtholders can then commence Chapter 7 of the bankruptcy code, or let the firm continue under the current debt contract. If debtholders have not commenced bankruptcy, the manager chooses one of the following actions.

1. Continuation: the firms pays $P_{1}$ to the debtholders, and continues operations.

2. Liquidation: the firm defaults on the loan (i.e., does not pay $P_{1}$ ), terminates operations, and uses the available cash to pay its claimholders according to APR.

3. Workout: the manager defaults on the loan, approaches debtholders and renegotiates the debt without court intervention.

4. Chapter 11: the manager defaults on the loan and asks for court protection under Chapter 11 of the Bankruptcy Code.

If the firm is not liquidated in period 1, investment takes place, and profits are realized in period 2. At this stage, the firm is liquidated and the cash flow is distributed to claimholders. The sequence of events and decisions of the game is presented in Figure 1.

\section{The investment decision when renegotiation and bankruptcy are ruled out}

We now analyze the investment decision, assuming that the debt contract cannot be renegotiated. In this case, the only viable alternatives for the firm are continuation and liquidation. We first characterize the first best investment level, which is the investment level chosen by an all-equity firm, and then compare it to that of a leveraged firm. This enables us to characterize the conditions for over- and underinvestment. 


\begin{tabular}{lll} 
Time & \multicolumn{1}{c}{1} & 2 \\
$\begin{array}{l}\text { Debt is issued with } \\
\text { promised payments }\end{array}$ & $\begin{array}{l}X \text { is realized to all. } \alpha \text { is } \\
\text { revealed to the manager. } \\
P_{1} \text { and } P_{2} .\end{array}$ & $\begin{array}{l}\text { Thebtholders learn } \alpha \text { with } \\
\text { probability } r . \text { They may } \\
\text { file a Chapter } 7 \text { petition. } \\
\text { The manager makes } \\
\text { investment/negotiations } \\
\text { decisions. }\end{array}$ \\
& $\begin{array}{l}\text { distributed to all } \\
\text { claimholders. }\end{array}$
\end{tabular}

Where

$X$ is the cash flow in period 1 .

$\alpha$ is the quality parameter of the production technology.

$r$ is the probability that debtholders' investigation succeeds.

Figure 1. Sequence of events. $X$ is the cash flow in period $1, \alpha$ is the quality parameter of the production technology, $r$ is the probability that debtholders' investigation succeeds.

\subsection{THE INVESTMENT DECISION OF AN ALL-EQUITY FIRM}

When an all-equity firm continues operations, the owner/manager chooses the investment level $I$ that maximizes the firm's expected value from continuation:

$$
V_{c}(\alpha, X)=\operatorname{Max}_{I} \int_{0}^{\infty} f(I, \alpha) \nu \mathrm{d} G(v)-(I-X)
$$

s.t. $\quad I \geqslant 0$.

The integral represents the expected cash flow to the manager in period 2, and the last term represents the net investment in period 1. The solution to Problem (2) is denoted by $I_{F B}(\alpha)$. For expositional convenience we denote $I_{F B}(\alpha)$ by $I_{F B}$.

The firm continues operations if, under the first best investment level, $I_{F B}$, the continuation value $V_{c}(\alpha, X)$ exceeds the liquidation value $X$. Thus, the value of an all-equity firm, $V_{F B}$, is

$$
V_{F B}=\operatorname{Max}\left\{V_{c}(\alpha, X), X\right\} .
$$

\subsection{THE INVESTMENT DECISION OF A LEVERAGED FIRM}

When the firm has debt outstanding, it is important to specify the restrictions on dividends and investments. We assume that, in order to protect debtholders from excessive distribution of dividends, the debt contract limits the amount of dividends the manager can pay in period 1 . For simplicity, we assume that no dividend can be 
paid before the firm is liquidated, and that the manager can distribute a liquidating dividend only after paying the entire debt obligation, $P_{1}+P_{2}$. We also assume that no investment can be made unless $P_{1}$ is paid.

The firm's investment decision depends on whether or not the available funds for investment, $X-P_{1}$, exceed the required investment, $I$. When $X$ is sufficient to pay the first period debt obligation and make the desired level of investment, the excess fund, $E F$, defined by

$$
E F=\operatorname{Max}\left\{0, X-I-P_{1}\right\},
$$

is retained in the firm. If $E F$ is larger than $P_{2}$, debt is riskless, the firm is not in financial distress and the investment problem of the manager is identical to that of an all-equity firm. If $E F$ is positive but less than $P_{2}$, the firm is in financial distress and the optimal investment level when the firm continues operations is the solution to

$$
\begin{aligned}
& V_{c}(\mu \mid E F>0)=\operatorname{Max}_{I}\left\{\int_{\left(P_{2}-E F\right) / f(I, \alpha)}^{\infty}\left(f(I, \alpha) v+E F-P_{2}\right) \mathrm{d} G(v)\right\} \\
& \text { s.t. } \quad X-P_{1} \geqslant I \geqslant \operatorname{Max}\left\{0, X-P_{1}-P_{2}\right\}
\end{aligned}
$$

where $\mu \equiv\left(\alpha, X, P_{1}, P_{2}\right)$. Because $E F$ is added to the cash flow of period 2, the integrand represents the cash flow to the owner/manager in period 2 , and it is positive whenever $v$ is larger than $\left(P_{2}-E F\right) / f(I, \alpha)$.

When the available fund for investment is less than the amount the firm needs, the manager must inject money to the firm. For simplicity we assume that the manager can use his own resources. The required fund, $R F$, is defined by

$$
R F=\operatorname{Max}\left\{0, I+P_{1}-X\right\} .
$$

When $R F$ is positive the firm is in financial distress and the manager chooses an investment level that solves

$$
\begin{aligned}
& \left.V_{c}(\mu \mid R F \geqslant 0)=\operatorname{Max}_{I}\left\{\int_{P_{2} / f(I, \alpha)}^{\infty} f(I, \alpha) v-P_{2}\right) \mathrm{d} G(\nu)-R F\right\} \\
& \text { s.t. } I \geqslant \operatorname{Max}\left\{0, X-P_{1}\right\} .
\end{aligned}
$$

The integrand represents the cash flow to the manager in period 2, and RF is his additional investment in period 1.

The optimal investment of a leveraged firm, $I^{*}$, solves Problem (5) or Problem (7), whichever yields the larger payoff to the owner (unless $X<P_{1}$, in which case $I^{*}$ solves Problem (7)). The value to the manager when the firm continues and invests $I^{*}$ is denoted by $V_{c}(\mu)$.

For low values of $X$, the optimal investment level is the solution to Problem (7). In this case, the manager invests less than the first best investment level. The 
manager under-invests because the new investment increases debt value by more than the project's NPV. For higher values of $X$ for which the firm has excess fund and it is still in financial distress, the optimal investment level is the solution to Problem (5). In this case, the manager over-invests because he invests debtholders' money. ${ }^{5}$

In addition, debt also distorts the continuation/liquidation decision. Upon liquidation, the manager must pay the debt obligations $P_{1}+P_{2}$ to the debtholders. Thus, the liquidation value for the manager is

$$
V_{L}=\operatorname{Max}\left\{X-P_{1}-P_{2}, 0\right\},
$$

which is smaller than the liquidation value of an all-equity firm, $X$. The manager continues and invests if doing so yields more than $V_{L}$. Therefore, the manager's value in the presence of debt is

$$
V^{*}=\operatorname{Max}\left\{V_{c}(\mu), V_{L}\right\} .
$$

The manager liquidates too often when $X \leqslant P_{1}$ because he has to add $P_{1}-X$ to the firm in order to continue operations. The manager continues too often when $X>P_{1}+P_{2}$ because if he liquidates he must pay $P_{1}+P_{2}$ to debtholders. If he continues, he has to pay only $P_{1}$, and can use the remaining funds, including $P_{2}$ for investment. Proposition 1 summarizes the distorted investment incentives discussed above.

\section{PROPOSITION 1}

\section{Under-investment}

There exist values of $X$ and $\alpha$ such that a leveraged firm invests less than the first best investment level, $I^{*}<I_{F B}$.

\section{Over-investment}

There exist values of $X$ and $\alpha$ such that a leveraged firm invests more than the first best investment level, $I^{*}>I_{F B} \cdot{ }^{6}$

The exact values of $X$ and $\alpha$ that result in under- and over-investment are characterized in Lemmas A(1) through A(5) in the Appendix, and are presented

\footnotetext{
5 These claims are proved in the Appendix. Note that the firm's excess funds and, therefore, its incentive to over invest, result from the constraint on dividend payments. If all the funds could be paid out as dividends, the required funds would be positive and there would be no 'free cash flows' to over invest. Nevertheless, our results hold when shareholders can take dividends, as long as it is bounded so that some funds have to be retained. To have excess funds, the dividend should be lower than $X-I-P_{1}$. For any given dividend, there is high enough $X$ satisfying this constraint. In practice, such restrictions exist to protect debtholders from being left with an empty shell.

6 Note that these cases include the continuation/liquidation decision. When $I^{*}=0<I_{F B}$ a leveraged firm liquidates inefficiently. When $I^{*}>0=I_{F B}$ a leveraged firm continues inefficiently.
} 
in Figures 3 and 4. These values are important for the derivation of the empirical implications in Section 6. The only relevant result for the analysis in the next three sections is that both over- and under-investment exist.

\section{Bankruptcy Laws and Outcomes}

We now introduce the bankruptcy law into the analysis. Before we analyze the bankruptcy game, we now discuss our view of the purpose of the bankruptcy law. Our premise is that the role of the bankruptcy law is to enhance economic efficiency by both increasing the debt capacity of firms and implementing efficient liquidation policy whenever possible. Specifically, we postulate that the purpose of Chapter 7 of the bankruptcy law is to enable creditors to curb the manager whenever they learn (with probability $r$ ) that the manager has incentives to reduce the value of the firm, and to maximize its debt capacity. To maximize debt capacity, debtholders must get the highest cash flow possible. This is consistent with the rules governing Chapter 7, where, upon liquidation, the proceeds are paid according to APR. Similarly, we postulate that the role of Chapter 11 is to facilitate efficient reorganization when debtholders' investigation fails (which happens with probability $1-r$ ), while still maximizing the debt capacity of the firm. In what follows, we take the existence of these two chapters and their main features as given, and show their implications for the bankruptcy outcome. ${ }^{7}$

\subsection{CHAPTER 7 OF THE BANKRUPTCY LAW}

We now model the important features of Chapter 7 of the US bankruptcy law. When debtholders file a Chapter 7 petition, they have to disclose their information regarding managerial incentives to the court. The court decides whether to approve the filing and nominate a trustee to liquidate the firm. We assume that the court approves the filing and nominates a trustee whenever the disclosed information indicates that the manager has the incentive to reduce firm value. The trustee then sells the firm to the highest bidder and distributes the proceeds to claimholders according to strict APR.

Debtholders may file a Chapter 7 petition following either a successful investigation that indicates that the manager faces incentives to reduce firm value, or, otherwise, if the manager, in the process of initiating workout negotiations, provides the information to them when their investigation fails. In the first case, debtholders' decision is straightforward: it is a dominant strategy for them to file a

\footnotetext{
7 See Berkovitch and Israel (1995) for a formal derivation of an optimal bankruptcy law consisting of both a creditor chapter like Chapter 7 and a debtor chapter like Chapter 11. In what follows, we analyze the case where the debtholders do not learn the information. In the other case, they file for Chapter 7 when they learn the information.
} 
Chapter 7 petition when they can prove to the bankruptcy court that the manager has incentives to reduce firm value, and to do nothing otherwise. ${ }^{8}$

The more interesting and revealing case is when the debtholders' investigation fails. As we show in the next section, the ability of debtholders to file a Chapter 7 petition has crucial and surprising implications for the choices made by managers of financially distressed firms even if the debtholders investigation fails. Therefore, in the remainder of the paper, we investigate the bankruptcy decision under the assumption that debtholders' investigation fails.

\subsection{CHAPTER 11 OF THE BANKRUPTCY LAW}

We assume that upon filing a Chapter 11 petition, the manager discloses the information about the quality parameter $\alpha$ to the debtholders and the court. This assumption simplifies the analysis since negotiations are done under symmetric information. Upon disclosure the firm bears the disclosure cost $K_{d}$. Since disclosure is costly, the manager does not disclose the information unless he wants to renegotiate the debt.

Before the manager can file for Chapter 11, he must petition the court for approval. We assume that the court approves the petition only if there are economic gains from renegotiation. Otherwise, the court dismisses the petition as per Section 305 of the Bankruptcy Code for not being filed 'in good faith'. In this respect, we assume that 'good faith' corresponds to the existence of economic gains from negotiations. When the manager's petition is approved, the firm bears a fixed cost, $K_{c}$. This cost may represent legal fees, loss of reputation, etc.

The main features of Chapter 11 that we incorporate are as follows. The owner/manager controls the firm ('debtor-in-possession'). He gets protection from creditors through a statutory stay, called the 'automatic stay', of most creditors' remedies such as lawsuits, setoffs and foreclosures during the Chapter 11 proceedings. The bankruptcy court determines the negotiation agenda: which party is to submit a reorganization plan and when the other party should respond. The only constraint on the negotiation agenda is that the manager has the exclusive right to propose a reorganization plan within 120 days after the petition for Chapter 11 is approved. We incorporate this feature by giving the manager a first mover advantage in the formal game. The judge can use cram down to force a class to accept an offer if it is 'fair' and 'equitable'.

The negotiation game in Chapter 11 consists of three parties: a manager, debtholders, and a judge. The game evolves in stages in which one party, the manager or debtholders, makes an offer and the other party accepts or rejects it. We capture the role of the judge by assuming that at each stage the judge determines who is to submit a proposal. In addition, at each stage, the judge can cram down a proposal if it is not accepted. The automatic stay is modeled by assuming that

\footnotetext{
8 When liquidation is costly, debtholders follow the exact same strategy, but now the liquidation value is net of the liquidation cost.
} 
debtholders cannot sue the firm or file a Chapter 7 petition after the manager has commenced Chapter 11. follows.

The sequence of events at any stage of the negotiation game in Chapter 11 is as

1. The judge decides which party is to submit a proposal.

2. That party submits an offer that consists of a cash payment, $P_{n}$, to be paid by the firm to debtholders in exchange for the outstanding debt. ${ }^{9}$

3. The respondent accepts or rejects the offer. If the respondent accepts, the game ends and the payment is made.

4. If the respondent rejects, the judge can cram down the offer. If he does not, the game moves to the next stage.

We assume that moving to the next stage involves a costly delay, represented by a discount factor $\delta$. The delay costs represent the (increases in) direct costs to lawyers, accountants, etc., the (increases in) indirect costs such as a deterioration in the firm's reputation and the (increases in) costs related to relationships with suppliers and buyers. In addition, to be consistent with Chapter 11 rules, the judge has to give the manager the right to propose first. In Proposition 2, we show the range of reorganization outcomes that the judge can implement.

\section{PROPOSITION 2}

The judge, by having the ability to cram down and by controlling the negotiation agenda, can implement any payoff to the owner/manager in the range $\left[(1-\delta)\left(V_{F B}-K\right),\left(V_{F B}-K\right)\right]$, where $K=K_{d}+K_{c}$.

For now, we do not model how the judge determines the outcome of Chapter 11. Instead, we analyze the game for any given strategy of the judge. We denote by $P^{*}$ the payoff to debtholders that results from the judge's strategy. Then, the payoff to the owner/manager, $V\left(P^{*}\right)$, is

$$
V\left(P^{*}\right)=V_{F B}-K-P^{*} .
$$

The only restriction we impose on $P^{*}$ is that the induced payoff to the owner/manager, $V\left(P^{*}\right)$, belongs to the interval $\left[(1-\delta)\left(V_{F B}-K\right),\left(V_{F B}-K\right)\right]$.

In our model, the parties agree on the reorganization plan without delay, because, after disclosure, negotiations take place under symmetric information. In practice, it may take a considerable amount of time to reach an agreement in Chapter 11. This may result from asymmetric information, uncertainty about the true situation of the firm, the time it takes to evaluate proposals and information, etc. We do not analyze these possibilities.

\footnotetext{
9 Since negotiations take place under symmetric information, any type of securities swap that eliminates debt (such as equity for debt swap) is equivalent to a cash payment.
} 


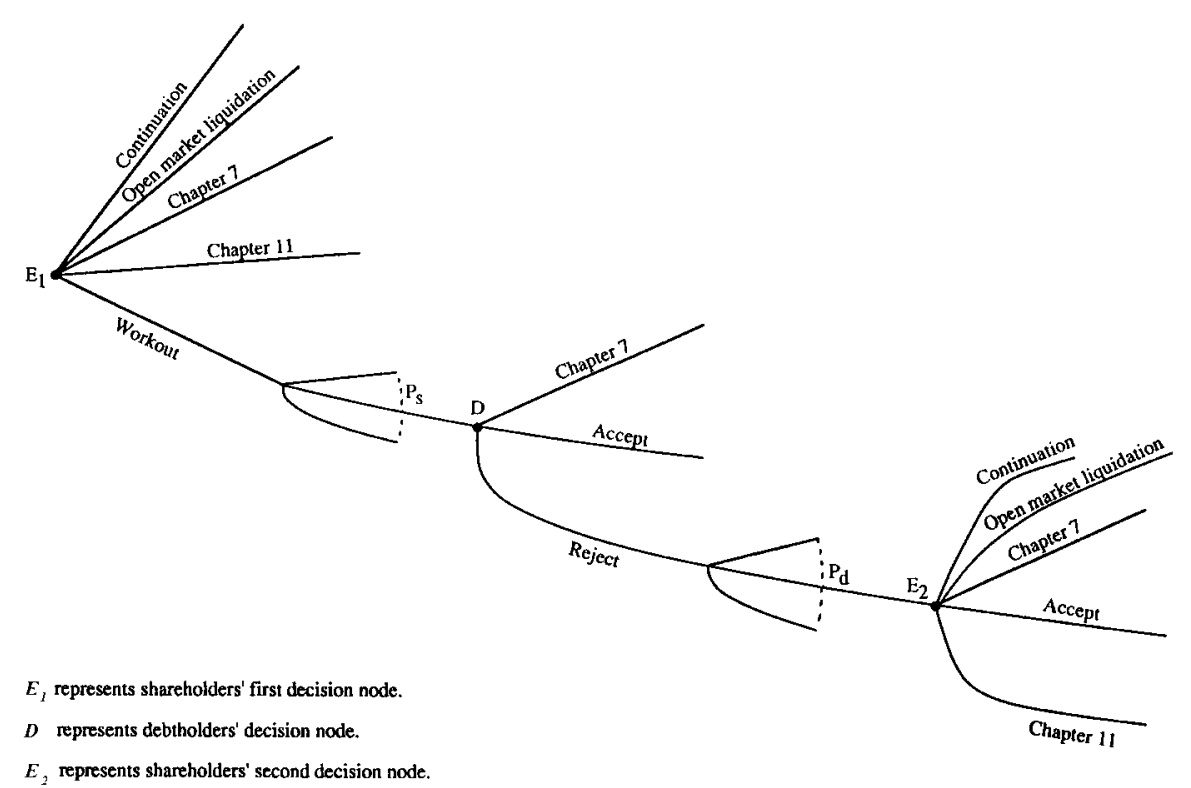

Figure 2. The bankruptcy and renegotiation game. $E_{1}$ represents shareholders' first decision node, $D$ represents debtholders' decision node, $E_{2}$ represents shareholders' second decision node.

\section{Workout Negotiations}

So far we have focused on formal bankruptcy as a mean of renegotiating the debt contract. We now analyze renegotiations of the debt contract in an out-ofcourt workout. As in the case of negotiations in Chapter 11, when the manager initiates workout negotiations, he has to disclose the information about the quality parameter $\alpha$. As before, the firm bears the disclosure costs, $K_{d}$.

The sequence of events of the workout game is described in the bottom branch of Figure 2 and is as follows. After the disclosure, the manager proposes a reorganization plan in which the firm offers to pay debtholders $P_{s}$ in exchange for the entire debt outstanding. Debtholders, in response, can choose one of the following three alternatives.

1. Accept the plan.

2. Reject the plan and propose a counter plan in which they get $P_{d}$. We assume that there is a delay before debtholders submit their plan. As before, the delay $\operatorname{cost}$ is $\delta$. In response, the manager can either accept the counter plan, continue operations under the original debt contract, liquidate the firm, or commence Chapter 11.

3. Reject the manager's plan and file a Chapter 7 petition.

The following lemma describes the payoff to the manager in the workout game when the option of Chapter 7 is irrelevant. In the case of under-investment, the 
manager and the debtholders can solve the problem in a workout. Therefore, the judge will reject a Chapter 7 petition, making it a non-viable option.

\section{LEMMA 1}

Let $W$ be the payoff to the manager in a workout, and suppose that debtholders cannot commence Chapter 7. Then,

$$
W= \begin{cases}(1-\delta)\left(V_{F B}-K_{d}\right)+\delta V\left(P^{*}\right) & \text { if } V\left(P^{*}\right)>V^{*}-K_{d} \\ (1-\delta)\left(V_{F B}-K_{d}\right)+\delta\left(V^{*}-K_{d}\right) & \text { if } V\left(P^{*}\right)<V^{*}-K_{d}\end{cases}
$$

The lower part of Equation (11) is obtained when the manager's payoff in Chapter 11 is below his continuation value without an agreement in workout. In this case, the manager receives in the bargaining a payoff between his continuation value absent an agreement, and the first best value. The upper part is obtained when the manager's payoff in Chapter 11 exceeds his continuation value without an agreement in workout. In this case, the value in Chapter $11, V\left(P^{*}\right)$, becomes the continuation value absent an agreement.

It can be seen that $W>V\left(P^{*}\right)$ and, therefore, a workout dominates Chapter 11 when the manager has the incentive to under invest. Consequently, the manager initiates a workout whenever $W$ is above his value from the best other alternative, $V^{*}$.

In the case of over-investment, the alternative of commencing Chapter 7 is relevant. After disclosure, debtholders can prove that commencing Chapter 7 enhances firm value. As a result, they can enforce the first best investment policy without any concessions. Therefore, if the manager initiates a workout, he must offer debtholders at least the debt value implied by the first best investment policy. This yields a lower payoff to the manager than his payoff from continuing operations without disclosing the incentives to over invest. Thus, the only relevant options for the manager are commencing Chapter 11 or continuing operations. ${ }^{10}$ In Chapter 11, the bankruptcy judge implements a reorganization plan yielding $V\left(P^{*}\right)$ to the manager. The manager commences Chapter 11 whenever $V\left(P^{*}\right)$ exceeds the continuation value, $V_{c}(\mu)$. Proposition 3 describes the manager's choice when the firm is in financial distress.

\section{PROPOSITION 3}

(a) Suppose the conditions for under-investment hold. Then, if $W>V^{*}$, the unique outcome of the game is for the manager to initiate a workout. Otherwise, he liquidates the firm if $V^{*}=V_{L}$, and continues operations if $V^{*}=V_{c}(\mu)$.

(b) Suppose the conditions for over-investment hold. Then, if $V\left(P^{*}\right)>V_{c}(\mu)$, the unique outcome of the game is for the manager to commence Chapter 11. The firm will be liquidated in Chapter 11 if $V_{c}(\alpha, X)<X$, and will emerge if

\footnotetext{
$10 \mathrm{By}$ the nature of over-investment, liquidation is irrelevant in this case since it is dominated by continuation.
} 
$V_{c}(\alpha, X)>X$. If $V\left(P^{*}\right)<V_{c}(\mu)$, the manager will continue operations without renegotiation.

Proposition 3 implies that the manager and the creditors negotiate in a workout when the firm faces under-investment, and the cost of disclosure is low relative to the loss in value due to under-investment. The manager commences Chapter 11 when the firm faces over-investment, and the costs of Chapter 11 are low relative to the loss in value due to over-investment. The outcome of Chapter 11 is that the firm continues and invests optimally if continuation yields the highest value, and it is liquidated when liquidation yields the highest value. Otherwise, when disclosure and bankruptcy costs are relatively high, the firm continues or liquidate inefficiently.

The striking result of Proposition 3 is that firms commence Chapter 11 even though it is more expensive than a workout. Debtholders' ability to file a Chapter 7 petition discourages the manager from disclosing his information and privately negotiate with the debtholders in the face of over-investment. The protection provided to the manager in Chapter 11 encourages him to negotiate the debt contract in spite of the higher cost of Chapter 11. Thus, our theory is different from previous bankruptcy theories in that it predicts that Chapter 11 is more than a threat in the workout negotiations, and firms actually resort to it.

\section{A Comparison to Bankruptcy Laws and Practices}

In Proposition 2 we have demonstrated that the bankruptcy judge has the power to implement almost any outcome in Chapter 11. This has often been observed in bankruptcy cases, as evident by the widespread deviations form APR. This power of the bankruptcy judge has been criticized by many scholars on the ground that it enables managers to take advantage of creditors. Our theory provides a potential rationale for such deviations.

For tractability, we did not incorporate into the model some of the features of the bankruptcy code that we view as less important. For example, the bankruptcy code allows managers to file for Chapter 11 protection when the firm is already in Chapter 7. Similarly, creditors are allowed to ask to transform a Chapter 11 case into a Chapter 7 case. Thus, the role of the different bankruptcy chapters is not as clear cut as we have been presenting it here. These additional options may undermine our view of the role of bankruptcy court. If the manager can escape liquidation in Chapter 7 by commencing Chapter 11, Chapter 7 is no longer a viable option for creditors in the workout game, and our premise that Chapter 11 is needed to (selectively) limit the power given to creditors in Chapter 7 may no longer be valid. This will be the case, unless the judge prevents the manager from taking advantage of creditors, as explained below.

The manager's option to commence Chapter 11 and his payoff there depend on the judge's decisions and actions. The judge can reject the manager's petition, or 
give the manager a low payoff in Chapter 11 whenever the manager attempts to convert a Chapter 7 case into a Chapter 11 case. Thus, if the role of the bankruptcy court that we are advancing here is understood by the bankruptcy judge, he can support it either by rejecting a Chapter 11 filing of a manager who uses it strategically to avoid a justified Chapter 7 case, or by giving the manager a low payoff in a case where Chapter 11 follows Chapter 7. It is an empirical issue whether bankruptcy judges think or behave this way. For our analysis to be valid, it is required that the manager and creditors believe that, with high enough likelihood, the judge will stick to the Chapter 7 payoffs if the creditors disclose the information first.

The actions of the bankruptcy court are also important for the derivation of empirical predictions, since they affect both the method of renegotiation chosen in equilibrium, and its outcome. Since we have no evidence on how bankruptcy judges actually make decisions, our procedure will be to assume a given court's behavior, and then derive empirical predictions given this assumed behavior. Thus, we will derive joint predictions regarding the bankruptcy court's behavior, and the actual empirical predictions regarding bankruptcy choices and price effects. Consistent with our theory, we will assume in the derivation of the empirical predictions that the bankruptcy court understands its role the way we have described it, and tries to alleviate the investment inefficiencies caused by financial distress while minimizing deviations from APR, in order to maximize debt capacity. This assumption implies that the bankruptcy court grants the manager the smallest payoff necessary to induce him not to over invest. That is, the judge sets $P^{*}$ so that $V\left(P^{*}\right)=V_{c}(\mu)$.

\section{Empirical Implications}

In this section we derive the empirical implications of our theory. For this, a discussion of the interpretation of different choices and variables of the model is in order. The essence of the firm's choice between liquidation, continuation, and reorganization is who controls the firm's assets. In liquidation, control of the assets is transferred to a new management team. In continuation, control is maintained by the incumbent management team. In reorganization, control may be maintained or transferred according to the plan adopted.

In the model, we identify liquidation with assets sale. In practice, transfer of control, or managerial turnover, can also be done via other control mechanisms such as takeovers, litigations, and pressure by the board of directors. ${ }^{11}$ Therefore, our empirical results regarding liquidation apply to all the mechanisms for transfer of control. Another important implication of this interpretation is that, according to our theory, emergence of firms from Chapter 11 under their original name but with a different management team, should be considered as liquidation.

\footnotetext{
11 See Gilson (1989) for an analysis of managerial turnovers in financial distress.
} 


\subsection{THE OUTCOME AND LIKELIHOOD OF WORKOUT, CHAPTER 11, AND LIQUIDATION}

In this section we analyze the probabilities and the associated payoffs of the different alternatives for reorganization. We first study the payoffs to the manager, as measured by the value of equity, and to debtholders in reorganization. A direct implication of Proposition 3 is that in order to enter Chapter 11, the owner/manager must be compensated above his payoff under strict APR. This holds also for a workout, because the manager has to be compensated to undertake good investment projects. This is summarized in Proposition 4.

\section{PROPOSITION 4}

APR is violated in both Chapter 11 and workout.

Franks and Torous (1989), Eberhart et al. (1990), Weiss (1990), and Daigle and Maloney (1990) investigating a sample of firms that emerged from Chapter 11 found that APR is violated. Frank and Torous (1991) found violation of APR in workouts. We are not aware of any study documenting relative payoffs in Chapter 11 liquidations.

We now analyze how a firm's required fund, measured by the difference between new investments and available fund, affects the manager's choice between Chapter 11 reorganization and workout. The effect of required fund on the manager's decision enables us to compare firms in mature industries to firms in growth industries. Mature industries tend to have relatively high current cash flows and little growth opportunities. In our model this is represented by a high $X$ and a low $\alpha$. Consequently, firms in mature industries are more likely to have excess funds. On the other hand, firms in growth industries tend to have a low $X$ and a high $\alpha$, resulting in positive required funds. This leads to the following result.

\section{PROPOSITION 5}

Among the firms that renegotiate their debt contract, the proportion of firms commencing Chapter 11 is higher for firms in mature industries than for firms in growth industries.

Proposition 5 is supported by Gilson et al. (1990). They found that financial distress is more likely to be resolved through private negotiations when more of the firm's assets are intangible.

\subsection{THE EFFECTS OF DEBT MATURITY STRUCTURE}

So far we have assumed a fixed debt level, $P_{1}+P_{2}$, and a fixed debt maturity structure, $P_{1}$ and $P_{2}$. We now hold the debt level, $P_{1}+P_{2}$, fixed and investigate how changes in debt maturity structure affect the actions of financially distressed firms. In our two-periods model, holding the debt level fixed, an increase in $P_{1}$ cor- 
responds to debt with a shorter maturity. ${ }^{12}$ Debt with a shorter maturity increases the need for external funds and, therefore, increases the likelihood that the firm will face under-investment and will resort to a workout. Similarly, firms with long-term debt are more likely to commence Chapter 11 . This discussion is summarized in the next Proposition.

\section{PROPOSITION 6}

Holding the level of debt fixed, firms with a shorter maturity of debt are more likely to reorganize in a workout, and firms with a longer maturity of debt are more likely to commence Chapter 11.

Gilson et al. (1990) found that firms engaged in a workout owed more of their debt to banks. Since bank loans have a shorter maturity than privately placed and public debt, their finding is consistent with Proposition $6 .{ }^{13}$ Clearly, while this evidence is consistent with our theory, there are other appealing theories that yield a similar prediction. Gertner and Scharfstein (1991) also obtained that short-term debt implies a higher likelihood of under-investment and long-term debt results in a higher likelihood of over-investment. By contrast, in Heinkel and Zechner (1993) shortening the maturity of debt reduces under-investment in managerial effort.

We have assumed one creditor holding the entire debt. Usually, different creditors hold the short- and long-term debts. Although the short- and long-term debtholders may have conflict of interests, in our model this would not change firms' behavior in financial distress. Debtholders' payoff in Chapter $11, P^{*}$, can be allocated by the judge in any 'fair' and 'equitable' way, leaving the manager's payoff and incentives unaffected.

\subsection{PRICE EFFECTS}

The bankruptcy process is dynamic and consists of several consecutive events. Each event may convey information and, therefore, may lead to price changes. We consider the following order of announcements. First, the firm defaults on its loan payments and announces its intention to renegotiate the debt contract. This may lead to either a workout or a Chapter 11 filing. Second, the firm announces whether it is going to engage in a workout or commence Chapter 11. Third, the market learns whether the firm liquidates in or emerges from Chapter 11. We assume that at the announcement of default, the market has already learned the realization of

\footnotetext{
12 If there are more than two periods, the definition of long-term and short-term is less obvious and this result may not hold.

13 James (1987) found that the mean maturity for commercial bank loans is 5.6 years, for privately placed debt it is 15.3 years, and for public straight debt 18 years. It should be noted that the finding in Gilson et al. (1990) is also consistent with the hypothesis that bank loans are renegotiated in a workout and public debt in Chapter 11, because the holdout problem does not exist for the former but does exist for the latter.
} 
$X$, but does not know $\alpha$ and the outcome of the negotiation process. We also hold $P_{1}$ and $P_{2}$ constant.

We first analyze the last announcement in which the outcome of Chapter 11 becomes known. In Chapter 11 liquidation, the total value to claimholders is $X-K$. When the firm emerges from Chapter 11, it has additional value equal to the NPV of new investments. Thus, when a firm announces that it has emerged from Chapter 11, its total value increases. The same result holds for equity value in Chapter 11, $V\left(P^{*}\right)=V_{c}(\mu)$, because it increases with $\alpha$. These results are summarized in Proposition 7.

\section{PROPOSITION 7}

(a) In Chapter 11, a firm's total value increases upon announcement of emergence, and decreases upon liquidation.

(b) In Chapter 11, equity value increases upon announcement of emergence, and decreases upon liquidation.

The announcement effect on the value of debt is ambiguous. Since both firm value and equity value increase for firms that emerge from Chapter 11, debt value increases when the increase in total value dominates the increase in equity value, and decreases otherwise.

We now analyze the price reaction when the firm announces its choice between a workout and a Chapter 11 filing. Announcement of a workout reveals that the firm needs additional funds and announcement of a Chapter 11 filing indicates that the firm has excess funds. For a given $X$, this translates to a higher $\alpha$ in a workout, implying higher firm and equity values. It should be noted that for some values of $X$ there is no announcement effect since the choice of the type of negotiation is fully anticipated. ${ }^{14}$ This discussion is summarized in Proposition 8.

\section{PROPOSITION 8}

In default, total firm value and equity value increase upon the announcement of a workout and decrease upon the announcement of a Chapter 11 filing.

Gilson et al. (1990) found a positive two-day abnormal return of 0.007 for firms involved in a workout, and a negative two-day abnormal return of -0.167 for Chapter 11 firms.

\section{Conclusions}

In this paper we have presented a positive theory of financial distress based on agency considerations. We show that when the investment opportunities and the

\footnotetext{
14 For low enough $X$ only a workout is possible and, therefore, the announcement of a workout conveys no news. When $X$ is relatively high, only Chapter 11 is possible and, therefore, the announcement of Chapter 11 conveys no news.
} 
financial structure of a firm lead to under-investment, a workout can eliminate the inefficiency. When the firm faces incentives to over invest, the inefficiency may be eliminated in Chapter 11, because a workout is no longer a viable alternative. The theory yields a number of empirical predictions regarding the resolution of financial distress, the effects of debt maturity structure, and price effects.

Our model can be extended into several interesting directions. Perhaps the most interesting one is to investigate the optimal contracting at the time the firm is established. In the paper we took the initial debt contract and the basic structure of the firm as given. It is an open question whether these contracts are optimal when the renegotiation methods and costs are taken into consideration.

Another interesting extension is to analyze the reorganization process under asymmetric information. We have assumed that negotiations are conducted under symmetric information. Thus, in our model, firms choose the appropriate negotiating mechanism right away, and agreement is reached without delay. Extending the model to allow for negotiations under asymmetric information may provide new insights into why firms may start negotiations in workout and then commence Chapter 11, and the length of time it takes to reach an agreement.

Our model focuses on the case where debtholders negotiate as a single group, thus avoiding the implications of hold-out problems. This demonstrates that even with a single creditor the choice of the negotiating method is important. The insight and the predictions of our theory are different from those of Gertner and Scharfstein (1991) which build on the hold-out problem. Combining these two approaches may add valuable insight into the understanding of the bankruptcy decision.

\section{Appendix}

The proof of Proposition 1 consists of Lemmas A(1) through A(5) below. We now describe Figures 3 and 4 that help understanding the proof.

Figure 3 describes the investment incentives given continuation for different levels of $\alpha$ and $X$. The bottom line, $X_{R F}(\alpha)$ (to be defined in Lemma $\mathrm{A}(2)$ ), describes pairs of $\alpha$ and $X$ below which the firm under invests. The line above it, $X^{c}(\alpha)$ (to be defined in lemma $\mathrm{A}(4)$ ), divides the area in which $R F=0$ into two regions. Below $X^{c}(\alpha)$ the firm under invests, and above it, the firm over invests. Pairs of $\alpha$ and $X$ between the lines $X_{E F}(\alpha)$ and $X_{F B}(\alpha)$ (to be defined in Lemma A(3)) result in over-investment. Pairs of $\alpha$ and $X$ above $X_{F B}(\alpha)$ result in the first best investment level.

Figure 4 describes the continuation decision for $X \leqslant P_{1}+P_{2}$. Define by $\alpha_{U}$ the critical quality parameter such that an all-equity firm continues (and invest) iff $\alpha>\alpha_{U}$ and by $\alpha_{L}(X)$ the critical quality parameter (as a function of $X$ ) such that a leveraged firm continues iff $\alpha>\alpha_{L}(X)$. Since in this case the liquidation value of a leveraged firm is zero, it continues if its value from continuation, $V_{c}(\mu)$, is positive. The $X$ that induces the right continuation decision is $X_{c}$ (to be defined in Lemma $\mathrm{A}(5)$ ). When $X=X_{c}$, the value from continuation is positive for any 


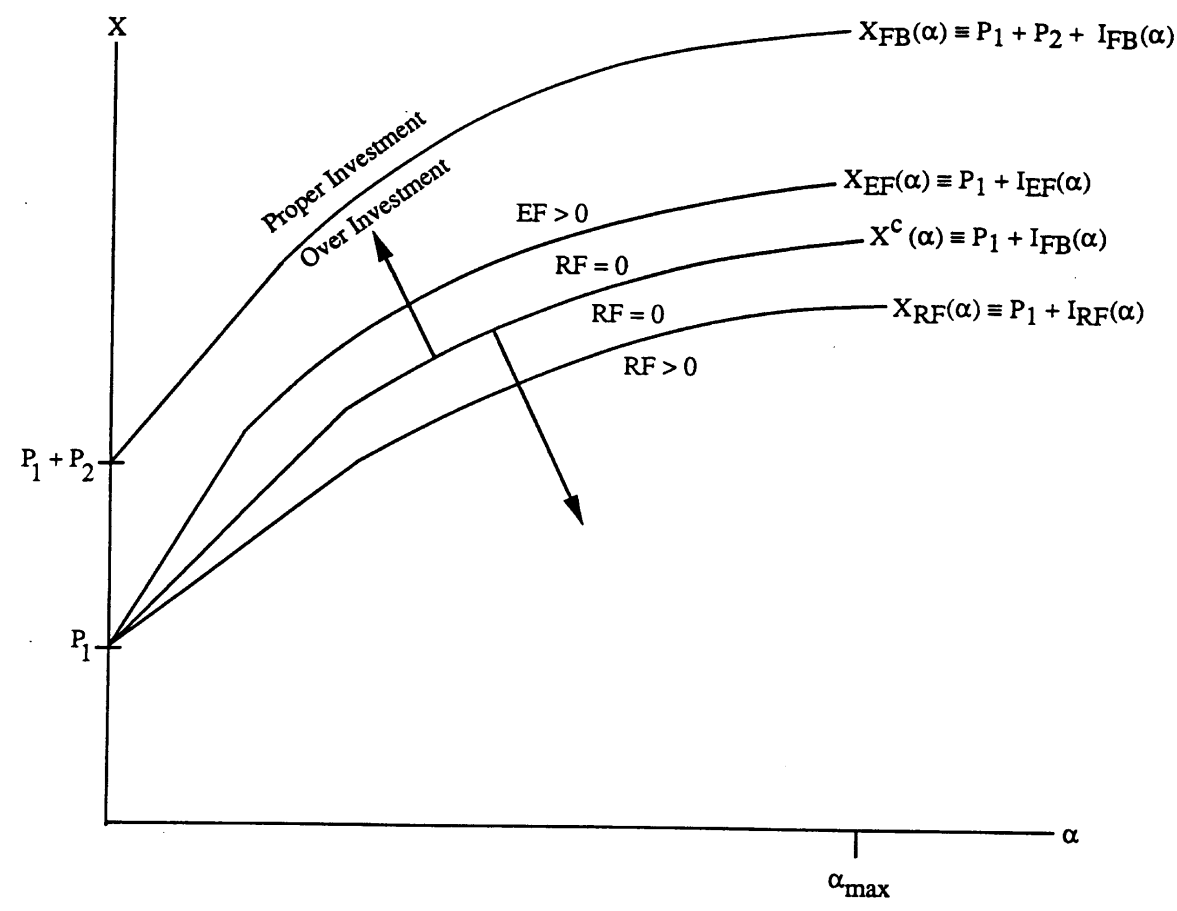

Figure 3. Over-and-under investment (given continuation). The bottom line, $X_{R F}(\alpha)$ (defined in Lemma A(2)), defines pairs of $\alpha$ and $X$ below which the firm under invests. The line above it, $X^{c}(\alpha)$ (defined in Lemma $\mathrm{A}(4)$ ), divides the area in which $R F=0$ into two regions. Below $X^{c}(\alpha)$ the firm under invests and above it the firm over invests. Pairs of $\alpha$ and $X$ between the lines $X_{E F}(\alpha)$ and $X_{F B}(\alpha)$ (defined in Lemma A(3)) result in over-investment. Pairs of $\alpha$ and $X$ above $X_{F B}(\alpha)$ result in the first best investment level.

$\alpha>\alpha_{L}(X)=\alpha_{U}$ and is negative otherwise. For $X<X_{c}$, (e.g., $X=P_{1}$ in Figure 4), the critical value of $\alpha, \alpha_{L}(X)$ is larger than $\alpha_{U}$. Thus, when $X<X_{c}$ (e.g., $\left.X=P_{1}\right)$, a viable firm with $\alpha \in\left(\alpha_{U}, \alpha_{L}(X)\right)$ liquidates. Similarly, for $X>X_{c}$ (e.g., $X=P_{1}+P_{2}$ in Figure 4), a non-viable firm with $\alpha \in\left(\alpha_{L}(X), \alpha_{U}\right)$ that should liquidate, will continue its operations.

\section{LEMMA A(1)}

The investment level that solves Problem (2), $I_{F B}$, is smaller than the investment level that solves Problem (5), $I_{E F}$, and is larger than the investment level that solves Problem (7), $I_{R F}$.

Proof. The first order condition for interior solution for Problem (2) is

$$
f_{I}(I, \alpha)=\frac{1}{E(v)}
$$

where $E(v)$ is the expected value of $v$. 


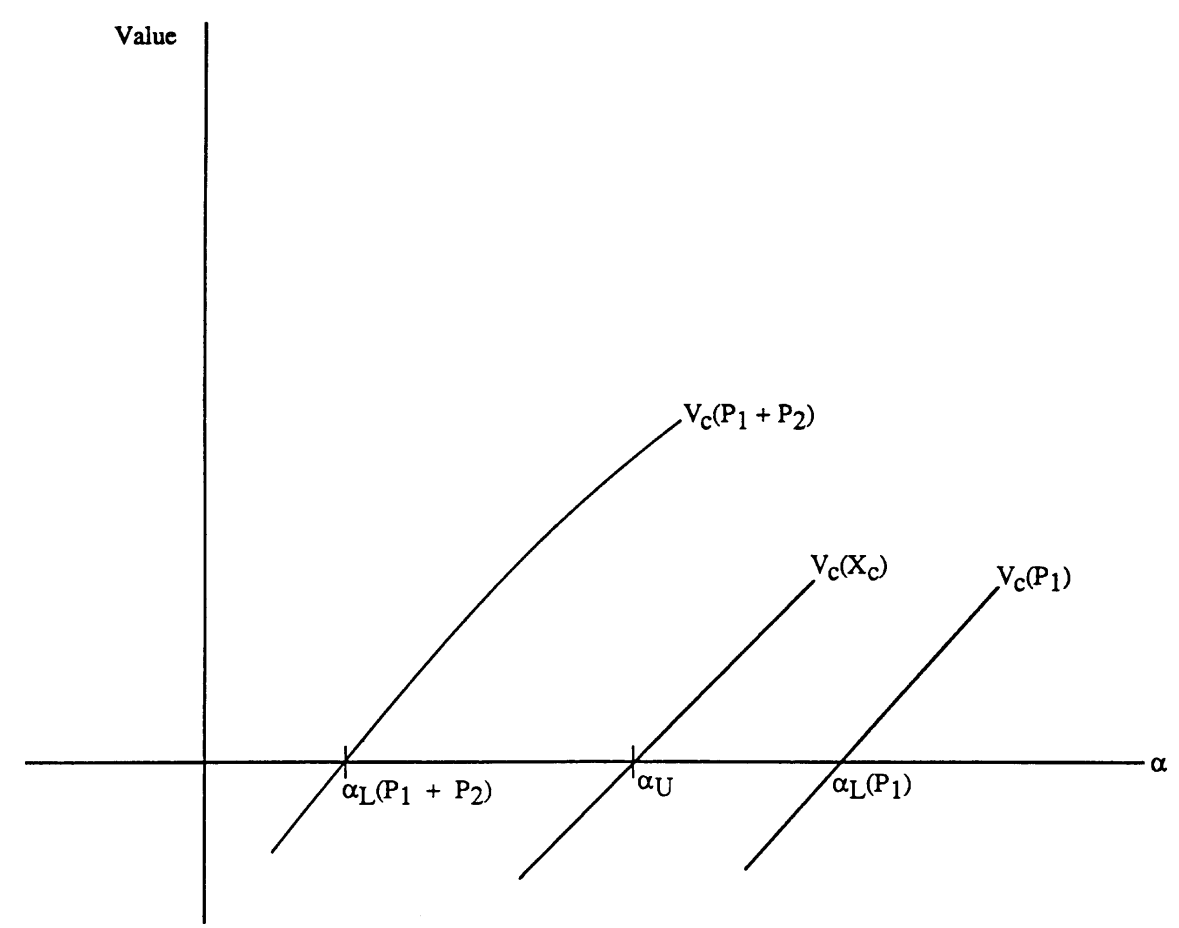

Figure 4. The continuation decision (for $X \leqslant P_{1}+P_{2}$ ). The firm continues if its value from continuation, $V_{c}(\mu)$, is positive. The $X$ that induces the right continuation decision is $X_{c}$ (defined in Lemma A(5)). When $X=X_{c}$, for any $\alpha>\alpha_{U}$, the value from continuation is positive. For $X<X_{c}$, e.g., $X=P_{1}$, the critical value of $\alpha$ is $\alpha_{L}\left(P_{1}\right)$. When $X=P_{1}$, for any $\alpha$ in the range $\left(\alpha_{U}, \alpha_{L}\left(P_{1}\right)\right)$, a viable firm liquidates. Similarly, for $X>X_{c}$, e.g., $X=P_{1}+P_{2}$, a non-viable firm will continue in the range $\left(\alpha_{L}\left(P_{1}+P_{2}\right), \alpha_{U}\right)$.

The first order condition for interior solution for Problem (5) can be written as

$$
f_{I}(I, \alpha)=\frac{1}{E\left(\nu \mid v \geqslant \frac{P_{2}-E F}{f(I, \alpha)}\right)}
$$

where $E\left(v \mid v \geqslant\left[\left(P_{2}-E F\right) / f(I, \alpha)\right]\right.$ is the conditional expectation of $v$, given that $v \geqslant\left(P_{2}-E F\right) / f(I, \alpha)$. Recall that $\left(P_{2}-E F\right) / f(I, \alpha)>0$, implying that the right-hand-side of Equation (A2) is smaller than that of Equation (A1). Thus, from the concavity of $f(I, \alpha)$ in $I$, it follows that $I_{E F}>I_{F B}$.

Similarly, the first order condition for Problem (7) and the concavity of $f(I, \alpha)$ in $I$ imply that $I_{R F}<I_{F B}$.

Q.E.D.

LEMMA A(2)

The interior solution to Problem (7), $I_{R F}$, is independent of $X$ and increases with $\alpha$. It exists iff $X<X_{R F}(\alpha) \equiv P_{1}+I_{R F}(\alpha)$. 
Proof. The derivative of Problem (7) with respect to $I$ is given by

$$
H(I, \alpha)=f_{I}(I, \alpha) \int_{P_{2} / f(I, \alpha)}^{\infty} v \mathrm{~d} G(v)-1 .
$$

$I_{R F}$ is independent of $X$, because $X$ is not an argument of Equation (A3).

We now show that $I_{R F}$ increases with $\alpha$. Since $\partial I_{R F} / \partial \alpha=-H_{\alpha} / H_{I}$, and since, by the second order condition of Problem (7), $H_{I}<0$, it follows that the sign of $\partial I_{R F} / \partial \alpha$ equals the sign of $H_{\alpha}$. Now,

$$
H_{\alpha}=f_{I \alpha}(I, \alpha) \int_{P_{2} / f(I, \alpha)}^{\infty} \nu \mathrm{d} G(v)+f_{I}(I, \alpha)\left(\frac{P_{2}^{2} f_{\alpha}(I, \alpha)}{f(I, \alpha)^{3}} g\left(\frac{P_{2}}{f(I, \alpha)}\right)\right)>0 .
$$

Therefore, $I_{R F}$ increases with $\alpha$.

For any $\alpha$, an interior solution for Problem (7) exists iff $R F>0$.

Since $R F=P_{1}+I_{R F}(\alpha)-X$, an interior solution for Problem (7) exists iff $X<X_{R F}(\alpha)$.

Q.E.D.

\section{LEMMA A(3)}

The interior solution to Problem (5), $I_{E F}$, decreases with $X$. It exists iff $X \in$ $\left(X_{E F}(\alpha), X_{F B}(\alpha)\right)$ where $X_{E F}(\alpha) \equiv P_{1}+I_{E F}\left(\alpha, X_{E F}(\alpha)\right)$ and $X_{F B}(\alpha) \equiv$ $P_{1}+P_{2}+I_{F B}(\alpha)$.

Proof. As $X$ increases $\left(P_{2}-E F\right) / f(I, \alpha)$ decreases and, therefore, the righthand side of Equation (A2) increases. It follows from the concavity of $f(I, \alpha)$ in $I$ that $I_{E F}$ decreases with $X$. To show the second part of the lemma, we first show that the interval $\left(X_{E F}(\alpha), X_{F B}(\alpha)\right)$ is non-empty. From Equations (A1) and (A2) it follows that $I_{E F}(\alpha, X)$ approaches $I_{F B}(\alpha)$ as $X$ approaches $X_{F B}(\alpha)$. Therefore, for $X$ close enough to $X_{F B}(\alpha), I_{E F}(\alpha, X)<I_{F B}(\alpha)+P_{2}$, implying $X_{E F}(\alpha)<$ $X_{F B}(\alpha)$.

At $X_{E F}(\alpha), E F=0$. Since $I_{E F}$ decreases with $X$, it follows that $E F>0$ iff $X>X_{E F}(\alpha)$. The proof is completed by noting that interior solution to Problem (5) exists iff $E F>0$.

Q.E.D.

For simplicity we will assume that $I_{E F}$ increases with $\alpha$. A sufficient condition for this is that the density function $g(v)$ is smaller than $\left(P_{2}-E F\right) / f(I, \alpha)$.

\section{LEMMA A(4)}

For $X \in\left(X_{R F}(\alpha), X_{E F}(\alpha)\right)$, the optimal investment level is $X-P_{1}$.

Proof. In this range Problems (5) and (7) have a corner solution where $R F=$ $E F=0$. From the definitions of $R F$ and $E F$, the investment level is $X-P_{1}$. Q.E.D.

Let $X^{c}(\alpha) \equiv P_{1}+I_{F B}(\alpha)$. It follows from Lemmas $\mathrm{A}(1)$ to $\mathrm{A}(4)$ that, when the firm continues, it will under invest if $X<X^{c}(\alpha)$, over invest if $X \in\left(X^{c}(\alpha)\right.$, $\left.X_{F B}(\alpha)\right)$ and will invest optimally if $X>X_{F B}(\alpha)$. 
We now analyze the continuation decision. Let $\alpha_{U}$ be the critical value of $\alpha$ such that an all-equity firm continues iff $\alpha>\alpha_{U}$. Assumption 2 implies that $\alpha_{U}>0$. A comparison of $V_{c}(\alpha, X)$ given by Problem (2) and the liquidation value $X$, yields that $\alpha_{U}$ is independent of $X$.

Let $\alpha_{L}(X)$ be the critical value of $\alpha$ such that a leveraged firm continues iff $\alpha>$ $\alpha_{L}(X)$. When $\alpha_{L}(X)>\alpha_{U}$ and $\alpha \in\left(\alpha_{U}, \alpha_{L}(X)\right)$, the firm liquidates inefficiently. When $\alpha_{L}(X)<\alpha_{U}$ and $\alpha \in\left(\alpha_{L}(X), \alpha_{U}\right)$, the firm continues inefficiently. The following lemma compares $\alpha_{U}$ and $\alpha_{L}(X)$.

\section{LEMMA A(5)}

There exists a critical value of $X, X_{c} \in\left(P_{1}, P_{1}+P_{2}\right)$ such that $\alpha_{L}\left(X_{c}\right)=\alpha_{U}$, $\alpha_{L}(X)>\alpha_{U}$ if $X<X_{c}$, and $\alpha_{L}(X)<\alpha_{U}$ if $X>X_{c}$.

Proof. It can be seen from Problems (5) and (7) that $V_{c}(\mu)$ continues and increases in both $\alpha$ and $X$. Consider first $X \leqslant P_{1}+P_{2}$. In this case, $V_{L}=0$ and the manager always continues if $V_{c}(\mu)>0$. Suppose now that $X=P_{1}$. A comparison of Problems (2) and (5) reveals that for any $\alpha$ the continuation value of an all-equity firm is larger than the continuation value for a manager of a leveraged firm. Thus, $\alpha_{L}\left(P_{1}\right)>\alpha_{U}$. Suppose now that $X=P_{1}+P_{2}$. If the firm used $X$ to pay debtholders $P_{1}+P_{2}$, its continuation incentives would be identical to those of an all-equity firm. Since the firm can use $P_{2}$ for investment, it has a stronger incentive to continue, resulting in $\alpha_{U}>\alpha_{L}\left(P_{1}+P_{2}\right)$. By continuity of $V_{c}(\mu)$ in $X, X_{c}$ as defined above exists. Since $V_{c}(\mu)$ increases with $\alpha$ and $X$, it follows that $\alpha_{L}(X)>\alpha_{U}$ if $X_{c}>X$, and $\alpha_{U}>\alpha_{L}(X)$ if $X>X_{c}$.

Consider now $X>P_{1}+P_{2}$. In this case, the liquidation value $V_{L}=X-P_{1}-P_{2}$ increases faster with $X$ than $V_{c}(\mu)$ does. Consequently, $\alpha_{L}(X)$ increases with $X$. At $X=X_{F B}, \alpha_{L}(X)=\alpha_{U}$. Thus, $\alpha_{U} \geqslant \alpha_{L}(X)$ for all $X>X_{c}$, including $X>P_{1}+P_{2}$.

Note that for all $\alpha$ and $X$ such that $\alpha \in\left(\alpha_{U}, \alpha_{L}(X)\right)$, the manager under invests because $I^{*}=0$ and $I_{F B}>0$. Similarly, for all $\alpha$ and $X$ such that $\alpha \in\left(\alpha_{L}(X)\right.$, $\alpha_{U}$ ), the manager overinvests because $I^{*}>0$ while $I_{F B}=0$. $\quad$ Q.E.D.

Proof of Proposition 1. Follows from Lemmas A(1)-A(5). $\quad$ Q.E.D.

Proof of Proposition 2. The bargaining outcome will eliminate the perverse investment incentives and will induce the manager to implement the first best investment policy. Therefore, the negotiation is over the value of the firm under the first best investment net of disclosure and Chapter 11 costs, $V_{F B}-K$, where $K=K_{d}+K_{c}$. For now we assume that $V_{F B}-K>0$. We show later that this is a necessary condition for firms to enter Chapter 11.

To understand the outcome of the game, consider the response of a party which has to accept or reject a reorganization plan, $P_{n}$. If the plan is accepted, the firm pays debtholders $P_{n}$ in exchange for the entire debt. Following the exchange, the firm has no debt outstanding and, therefore, the manager implements the first 
best investment policy. The resulting payoff to the manager is $V_{F B}-K-P_{n}$. This outcome also prevails when the plan is rejected by the respondent but the judge crams it down. If the plan is rejected and the judge does not cram it down, the game moves with delay to the next stage. The proposer submits a plan that gives the respondent exactly his value from rejection. This determines the equilibrium outcome of the negotiation game. The owner manager can guarantee at least $(1-\delta)\left(V_{F B}-K\right)$ because of the first mover advantage. It remains to show that the judge can implement any payoff in the range $S=\left[(1-\delta)\left(V_{F B}-K\right),\left(V_{F B}-K\right)\right]$. Let $V$ be a payoff in $S$. Let $P_{n}(V)$ be a plan that implements $V$ in the first stage, i.e., $P_{n}(V)$ satisfies $V=V_{F B}-K-P_{n}(V)$. The judge can implement $V$ in the first period using the following strategy:

1. Cram down any plan with $P_{n} \geqslant P_{n}(V)$ at stage 1 , and do not cram down otherwise.

2. If the manager offers $P_{n}<P_{n}(V)$ and debtholders reject, give debtholders the right to propose at every future stage.

Given this strategy, the unique subgame perfect equilibrium is for the manager to offer $P_{n}=P_{n}(V)$, for debtholders to reject, and for the judge to cram the offer down. (A payoff equivalent subgame perfect equilibrium is for the manager to offer $P_{n}=P_{n}(V)$ and for the debtholders to accept.) To see this, note that debtholders get, if the game reaches stage 2 , the whole cake, which has a discounted value of $\delta\left(V_{F B}-K\right)$ today. Thus, they reject any offer that results in a payoff in $S$. Therefore, the manager proposes at stage 1 the lowest value for debtholders that the judge crams down, namely $P_{n}(V)$.

Q.E.D.

Proof of Lemma 1. By backwards induction, consider node $E_{2}$ in Figure 2 where the manager responds to a debtholders' offer. Chapter 11 yields $V\left(P^{*}\right)$ to the manager and $P^{*}$ to the debtholders. If the manager rejects the offer and does not commence Chapter 11, he receives $V^{*}-K_{d}$. Therefore, he accepts any offer that yields him at least $\operatorname{Max}\left\{V^{*}-K_{d}, V\left(P^{*}\right)\right\}$. Therefore, debtholders' best offer is the highest $P_{d}$ which is still acceptable to the manager:

$$
V_{F B}-K_{d}-P_{d}=\operatorname{Max}\left\{V^{*}-K_{d}, V\left(P^{*}\right)\right\} .
$$

Solving for $P_{d}$ we get,

$$
P_{d}= \begin{cases}V_{F B}-K_{d}-V\left(P^{*}\right) & \text { if } V\left(P^{*}\right)>V^{*}-K_{d} \\ V_{F B}-V^{*} & \text { if } V\left(P^{*}\right)<V^{*}-K_{d} .\end{cases}
$$

Debtholders' offer, $P_{d}$, is their best counter offer (node $D$ in Figure 2). At this juncture, debtholders accept the manager's offer if $P_{s} \geqslant \delta P_{d}$ and reject it otherwise. Consequently, if the manager enters private negotiations, he offers

$$
P_{s}=\delta P_{d} .
$$


The manager's payoff in a workout is the total pie minus the amount paid to the debtholders. Combining Equations (A4), (A5), and (A6), yields the payoffs $W$ of lemma (1).

Q.E.D.

Proof of Proposition 3. Follows from the discussion preceding the proposition. Q.E.D.

Proof of Proposition 4. Suppose $P^{*}>P_{1}+P_{2}$. Then, the manager can pay the debt outside Chapter 11, implement the first best investment policy, and save Chapter 11 costs. Thus, the manager never commences Chapter 11. Therefore, when firms commence Chapter 11, $P^{*}<P_{1}+P_{2}$ and the owner manager obtains a positive payoff, i.e., absolute priority rule is violated. In a workout, since the value of risky debt is lower than $P_{1}+P_{2}$, and since debtholders' payoff is below their payoff under the original debt contract if the new project is undertaken, absolute priority rule is violated.

Q.E.D.

Proof of Proposition 5. Follows from the discussions in the text. Q.E.D.

Proof of Proposition 6. Fix $P_{1}+P_{2}$ and change $P_{1}$ and $P_{2}$.

Given that the firm continues operations, an increase in $P_{1}$ shifts the lower three lines in Figure 3 upward towards the upper line, $X_{F B}(\alpha)$, which is fixed because $P_{1}+P_{2}$ is fixed. This results in more cases of under-investment and less cases of over-investment. It remains to show the results for the continuation decision. We do it by showing that $V_{c}(\mu)$ increases with $P_{2}$, resulting in more continuations as $P_{2}$ increases.

Consider the case in which $E F>0$. From Problem (5) and Equation (8) it follows that only the sum $P_{1}+P_{2}$ affects the continuation decision. Therefore, in this case the continuation decision is not affected by the maturity of the firm's debt.

Consider instead the case in which $R F>0$. From Problem (7) it follows that

$$
\frac{\partial V_{c}}{\partial P_{2}}=1-\left[1-G\left(\frac{P_{2}}{f(I, \alpha)}\right)\right]>0 .
$$

Thus, the firm will continue for a larger set of $\alpha$. This results in more overinvestment and less under-investment.

It remains to show the result for $R F=E F=0$. From Problems (5) and (7) it follows that

$$
V_{c}(\mu)=\int_{P_{2} / f(I, \alpha)}^{\infty}\left(f\left(X-P_{1}, \alpha\right) v-P_{2}\right) \mathrm{d} G(v)
$$

and therefore,

$$
\frac{\partial V_{c}(\mu)}{\partial P_{2}}=\int_{P_{2} / f\left(X-P_{1}, \alpha\right)}^{\infty}\left(f_{I}\left(X-P_{1}, \alpha\right) v-1\right) \mathrm{d} G(v) .
$$


Using Equation (A3), Equation (A9) can be rewritten as

$$
\frac{\partial V_{c}(\mu)}{\partial P_{2}}=H\left(X-P_{1}, \alpha\right)+G\left(\frac{P_{2}}{f\left(X-P_{1}, \alpha\right)}\right) .
$$

The second order condition for Problem (7) implies that $H_{I}<0$. When $R F>0$, $I_{R F}>X-P_{1}$. Using these facts we obtain that

$$
\frac{\partial V_{c}(\mu)}{\partial P_{2}}>H\left(I_{R F}, \alpha\right)+G\left(\frac{P_{2}}{f\left(X-P_{1}, \alpha\right)}\right) .
$$

Now, the first order condition for Problem (7) implies that $H\left(I_{R F}, \alpha\right)=0$. Therefore, and because $G(\cdot)>0$, we have that $\partial V_{c}(\mu) / \partial P_{2}>0$.

Thus, the firm will continue for a larger set of $\alpha$. This results in more overinvestment and less under-investment.

Q.E.D.

\section{Proof of Proposition 7.}

(a) Follows from the discussions in the text.

(b) The firm emerges if $\alpha \geqslant \alpha_{U}$ and liquidates otherwise. In Chapter 11 the manager gets the value from continuation, $V_{c}(\mu)$. Since $V_{c}(\mu)$ increases in $\alpha$, the value of equity is higher when the firm emerges than when it liquidates. Q.E.D.

Proof of Proposition 8. We show that for a given $X$, firms that initiate a workout have higher $\alpha$ than firms that commence Chapter 11 .

Note that for $X<X_{c}$, where $X_{c}$ is defined in Lemma A(5), there is no overinvestment and therefore no Chapter 11. For $X$ in this range, there are no price effects. Therefore, we show the result for $X>X_{c}$. Let $\alpha^{c}(C)$ be the inverse image of $X^{c}(\alpha)$ : it is the $\alpha$ that solves $X=P_{1}+I_{F B}(\alpha)$. It follows that for $\alpha<\alpha^{c}(X)$ there is over-investment (given continuation) and for $\alpha>\alpha^{c}(X)$ there is underinvestment (given continuation). The manager over invests if $\alpha<\operatorname{Max}\left\{\alpha_{U}\right.$, $\left.\alpha^{c}(X)\right\}$, and under invests if $\alpha>\operatorname{Max}\left\{\alpha_{U}, \alpha^{c}(X)\right\}$. Since total firm value, $V_{F B}(\alpha$, $X)$, increases with $\alpha$, it is higher under a workout than under Chapter 11. Similarly, because $V\left(P^{*}\right)=V_{c}(\mu)$, the value to the manager, $V_{c}(\mu)$, increases with $\alpha$. Q.E.D.

\section{References}

Bebchuk, L. A. and Chang, H. F. (1990) Bargaining and the division of value in corporate reorganization, Working Paper, Harvard Law School.

Bergman, Y. Z. and Callen, J. L. (1991) Opportunistic underinvestment in debt renegotiation and capital structure, J. Financ. Econom. 29, 137-172.

Berkowitch, E. and Israel, R. (1995). Optimal bankruptcy laws across different economic systems, Working Paper, Carnegie Mellon University.

Brown, D. T. (1989) Claimholder incentive conflicts in reorganizations: the role of bankruptcy law, Rev. Financ. Studies 2, 109-123.

Bulow, J. I. and Shoven, J. B. (1978) The bankruptcy decision, Bell. J. Econom. 9, 437-456. 
Daigle, K. H. and Maloney, M. T. (1990) Residual claims in bankruptcy: an agency theory explanation, Working Paper, Clemson University.

Easterbrook, F. H. (1990) Is corporate bankruptcy efficient?, J. Financ. Econom. 27, 411-417.

Eberhart, A. C., Moore, W. T. and Roenfeldt, R. L. (1990) Security pricing and deviation from the absolute priority rule in bankruptcy proceedings, J. Finance 45, 1457-1469.

Flynn, E. M. (1989) Statistical analysis of Chapter 11, Mimeo, The Bankruptcy Division of the Administrative Office of the United States Courts.

Franks, J. R. and Torous, W. N. (1989) An empirical investigation of U.S. firms in reorganization, J. Finance 44, 747-769.

Franks, J. R. and Torous, W. N. (1991) How firms fare in workouts and Chapter 11 reorganizations, Working Paper, UCLA.

Gertner, R. and Scharfstein, D. (1991) A theory of workouts and the effects of reorganization law, $J$. Finance 46, 1189-1222.

Giammarino, R. M. (1989) The resolution of financial distress, Rev. Financ. Studies 2, 25-47.

Gilson, S. C. (1989) Management turnover and financial distress, J. Financ. Econom. 25, 241-262.

Gilson, S. C., John, K. and Lang L. H. P. (1990) Troubled debt restructuring: an empirical study of private reorganization of firms in default, J. Financ. Econom. 27, 315-353.

Green, R. C. and Juster, A. (1994) Financial structure, distress and restructuring, Working Paper, Carnegie Mellon University.

Harris, M. and Raviv, A. (1990). Capital structure and the informational role of debt, J. Finance 45, 321-349.

Heinkel, R. and Zechner, J. (1993) Debt payment structure, optimal default decisions and capital structure renegotiations, J. Econom. Management Strategy 2, 531-566.

James, C. (1987) Some evidence on the uniqueness of bank loans, J. Financ. Econom. 19, 217-235.

Weiss, L. A. (1990) Bankruptcy resolution: direct costs and violation of priority of claims, J. Financ. Econom. 27, 285-314.

White, M. J. (1980) Public policy toward bankruptcy: me-first and other priority rules, Bell J. Econom. 11, 550-564. 
